\title{
Tree-ring based reconstruction of the seasonal timing, major events and origin of rockfall on a case-study slope in the Swiss Alps
}

\author{
D. M. Schneuwly and M. Stoffel \\ Laboratory of Dendrogeomorphology, Department of Geosciences, University of Fribourg, Chemin du Musée 4, 1700 \\ Fribourg, Switzerland
}

Received: 19 November 2007 - Revised: 22 January 2008 - Accepted: 23 January 2008 - Published: 11 March 2008

\begin{abstract}
Tree-ring analysis has been used to reconstruct 22 years of rockfall behavior on an active rockfall slope near Saas Balen (Swiss Alps). We analyzed 32 severely injured trees (L. decidua, P. abies and P. cembra) and investigated cross-sections of 154 wounds.

The intra-annual position of callus tissue and of tangential rows of traumatic resin ducts was determined in order to reconstruct the seasonality of past rockfall events. Results indicate strong intra- and inter-annual variations of rockfall activity, with a peak $(76 \%)$ observed in the dormant season (early October - end of May). Within the growth season, rockfall regularly occurs between the end of May and mid July (21.4\%), whereas events later in the season appear to be quite rare $(2.6 \%)$. Findings suggest that rockfall activity at the study site is driven by annual thawing processes and the circulation of melt water in preexisting fissures. Data also indicate that $43 \%$ of all rockfall events occurred in 1995, when two major precipitation events are recorded in nearby meteorological stations. Finally, data on impact angles are in very good agreement with the geomorphic situation in the field.
\end{abstract}

\section{Introduction}

Rockfall is the free fall, bouncing or rolling of individual or a few rocks and boulders with volumes involved generally limited to a few cubic meters (Berger et al., 2002). Due to its hazard potential (Butler, 1983; Evans and Hungr, 1993), rockfall has become one of the most intensely studied geomorphic processes of the cliff zone in mountain areas. As a result, there exist a large number of studies analyzing rockfall mechanics, such as the movement (Ritchie, 1963; Erismann, 1986; Azzoni et al., 1995), the behavior during ground contact (Bozzolo and Pamini, 1986; Hungr and Evans, 1988) or

Correspondence to: D. Schneuwly

(dominique.schneuwly@unifr.ch) runout distances (Kirkby and Statham, 1975; Statham and Francis, 1986; Okura et al., 2000). Furthermore, there are a large number of studies on rockfall modeling (Guzzetti et al., 2002; Dorren et al., 2006; Stoffel et al., 2006b) or on long-term accretion rates of rockfall (Luckman and Fiske, 1995; McCarroll et al., 1998). In addition, research has focused on possible triggers of rockfall such as tectonic folding (Coe and Harp, 2007), freeze-thaw cycles (Gardner, 1983; Matsuoka and Sakai, 1999; Matsuoka, 2006), changes in the rock-moisture level (Sass, 2005), the thawing of permafrost (Gruber et al., 2004), the rising of mean annual temperatures (Davies et al., 2001) or the occurrence of earthquakes (Harp and Wilson, 1995; Marzorati et al., 2002).

In contrast, only a few studies have analyzed the evolution of rockfall activity with time or determined its seasonal behavior: In the 1970s, a number of observation-based studies was realized in North America (Luckman, 1976; Douglas, 1980; Gardner, 1980). Gardner's (1980) observations on rockfall and rockslides in Alberta (Canada) were, for instance, kept on a weekly basis over a period of two years. He observed a continuous, yet small background activity throughout the year with two peaks in rockfall activity in February-March and November-December. More recently, Sass (2005) installed more than 60 rockfall barriers in the Bavarian Alps so as to quantify rockfall activity over a period of four years. He concludes that the distribution of rockfall is highly variable in time and that rocks and boulders are triggered by a combination of a multitude of parameters.

While these studies yielded very precise datasets on daily variations of rockfall, they do neither represent complete time series within the year nor did they cover continuous period over several years. As a consequence, they have to be considered too short to assess rockfall activity with its seasonal variations over time.

In contrast to other mass-movement processes (e.g., Shroder, 1980; Braam et al., 1987; Wiles et al., 1996; Solomina, 2002), tree-ring analyses have only occasionally been

Published by Copernicus Publications on behalf of the European Geosciences Union. 


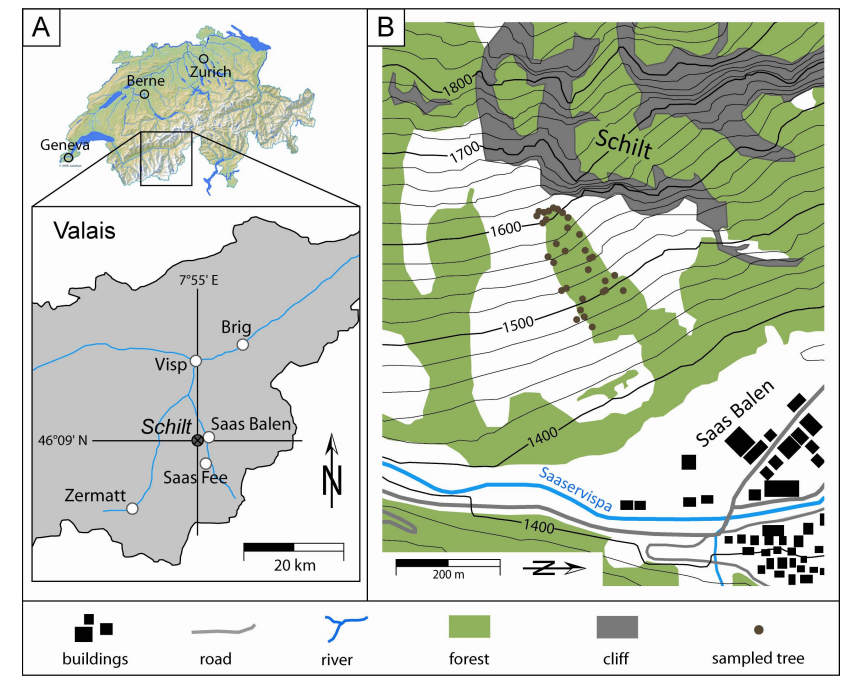

Fig. 1. (A). The study site is located in the Saas Valley near Saas Balen. (B). Sketch map of the study site and the position of the 32 trees sampled for analysis.

used to study past rockfall activity, mainly to determine sedimentation rates on scree slopes (Lafortune et al., 1997) or to reconstruct rates or the spatial occurrence of rockfall (Stoffel et al., 2005a; Perret et al., 2006).

In a similar way, dendrogeomorphology has rarely been applied to assess the seasonality of past mass-movement processes so far. Through the analysis of injuries and the adjacent callus tissue, Stoffel et al. (2005b) determined the seasonal timing of rockfall on a slope in the Valais Alps. Their results clearly indicate a peak in rockfall activity between October and May. More recently, the intra-annual position of tangential rows of traumatic resin ducts was used to separate previous snow avalanche from debris-flow events on a cone affected by both processes (Stoffel et al., 2006a) or to date past debris-flow activity with monthly precision (Stoffel et al., 2008).

It is therefore the aim of this study to close the gap between long-term but low seasonal and short-term but high seasonal resolution rockfall research by accomplishing a long-term study with a high seasonal resolution. Through the analysis of trees injured by rocks and boulders, we (i) reconstruct rockfall activity and possible event years; (ii) analyze the seasonal behavior of rockfall during the last 22 years so as to detect possible seasonal shifts of activity and (iii) compare the angles of the rockfall injuries as observed on the stem surface with the effective source area of falling rocks. Results were obtained from 123 cross-sections of 23 European larch (Larix decidua Mill.), eight Norway spruce (Picea abies (L.) Karst.) and one Swiss stone pine (Pinus cembraL.) trees growing in the transition zone of a rockfall slope in the Swiss Alps.

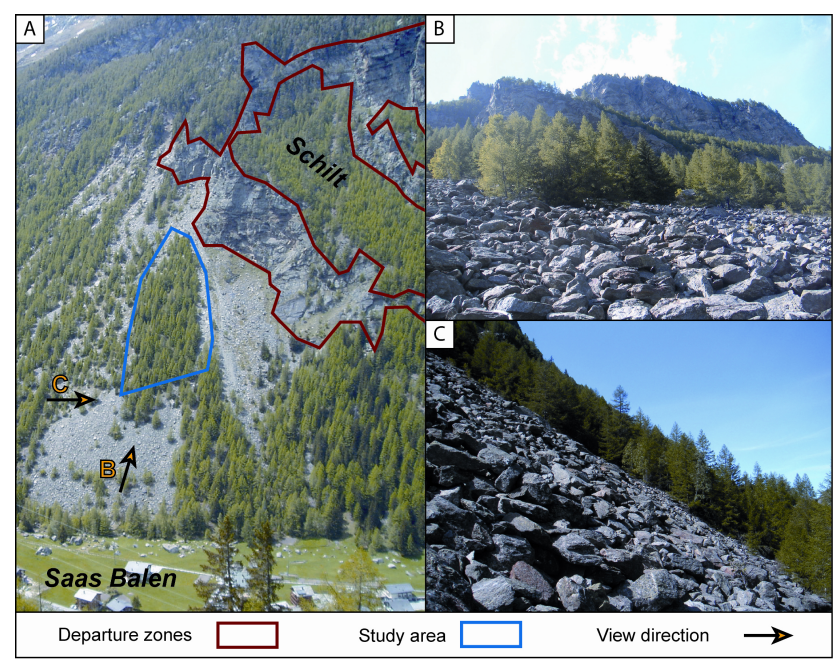

Fig. 2. (A). View of the study site and the departure zone. (B). View from to the cliffs generating rockfall. (C). Lateral view of the rockfall slope (mean slope angle $36^{\circ}$ ).

\section{Study area}

The study was conducted in a forest near Saas Balen $\left(46^{\circ}\right.$ $09^{\prime} 06^{\prime \prime} \mathrm{N}, 7^{\circ} 55^{\prime} 27^{\prime \prime} \mathrm{E}$ ) in the Valais Alps (Switzerland; Fig. 1A). The investigated forest stand is called "Schilt" and is located between 1470 and $1610 \mathrm{~m}$ a.s.l. on the eastnortheast facing slope descending from the Lammenhorn (3189 m a.s.1.). Rockfall frequently occurs on the slope, originating from disintegrated and glacially oversteepened cliffs at 1600-1900 m a.s.l (Figs. 1B and 2). In the departure zone, bedrock consists of micaceous schists belonging to Penninic crystalline layers, dipping SSE with an angle of $20^{\circ}$ (Bearth, 1973, 1980). The transition and deposition zones are covered with Quaternary talus and morainic deposits. Archival data and local toponomy indicate the presence of rockfall in the region since at least the early 18 th century, when rockfalls descended from the neighboring "Steinschlagwald" (= rockfall forest), destroying the old communal church (Ruppen et al., 1979). In contrast, other mass-movement processes such as debris flows or snow avalanches have neither ever been witnessed on the slope, nor is there geomorphic evidence for such processes.

On the study site, the volume of rocks resting on the talus slope does not normally exceed $1 \mathrm{~m}^{3}$, but there are a few blocks deposited on the valley bottom with volumes up to $50 \mathrm{~m}^{3}$, witnessing of major events in the past. The mean slope angle of the transition zone is $36^{\circ}$ (Fig. 2C) with only little variation between the top and the bottom. The forested study site covers about $8000 \mathrm{~m}^{2}$ and past rockfall deposits are covered with a centimetric soil layer. The zones outside the forest remain mostly free of vegetation and are covered with bare rocks and boulders. The stand at Schilt consists predominantly of $L$. decidua trees, accompanied by approximately 
$10 \%$ of $P$. abies and single $P$. cembra trees. There is no anthropogenic influence visible in the forest stand.

\section{Materials and methods}

\subsection{Sampling strategy}

Virtually all trees at the forest stand show clearly visible and severe growth disturbances (GD) caused by past rockfall events. On the study site, scars were the most prominent sign of previous rockfall activity. As the forest at Schilt has a protective function for the village of Saas Balen, only trees with a basal diameter $<15 \mathrm{~cm}$ were felled. We investigated the entire upper forest stand and headed for an even distribution of trees throughout the study site. However, there is some concentration of sampled trees at the upper and lateral limits of the study area, as small trees predominantly grow in these sectors.

The positioning of the selected trees on the geomorphic map was based on aerial photographs and realized with a measuring tape, as the use of GPS devices was not possible in the dense forest stand within the deep valley.

Data recorded for each tree included micro-topography or accumulation of rockfall deposits in the immediate vicinity of the tree. In addition, we noted tree-specific data including species, height, diameter at breast height, visible defects in its morphology such as e.g., scars (direction, surface and height of centre above ground level), broken crowns or branches, tilted stems or candelabra growth. We furthermore commented on neighboring trees if relevant.

Thereafter, photographs were taken of the entire tree and specific pictures for each wound so as to facilitate assigning GD to their triggering injury in the laboratory. Exclusively well-defined and clearly visible injuries were sampled at their maximum extension. In order to obtain a maximum of information, the sampling was realized using a handsaw, so as to obtain complete cross-sections from each injury.

\subsection{Tree-ring analysis and intra-annual dating of events}

The cross-sections were analyzed using standard dendrochronological methods (Stokes and Smiley, 1968; Bräker, 2002). Samples were first polished and tree rings counted, before tree-ring series were analyzed visually to identify GD caused by past rockfall.

The dating of past rockfall activity was based on the position of callus tissue and tangential rows of traumatic resin ducts (TRD) in L. decidua and P. abies, as both features are usually formed after cambium damage (Schweingruber, 1996, 2001). While callus tissue only occurs in the wood segment bordering the injury (Stoffel et al., 2005a, b; Perret et al., 2006), TRD can be even observed at some distance from the wound as well (Bollschweiler et al., 2007a; Stoffel, 2008). Bollschweiler et al. (2008) indicate a mean lateral TRD extension of $19 \%$ of the stem's circumference.

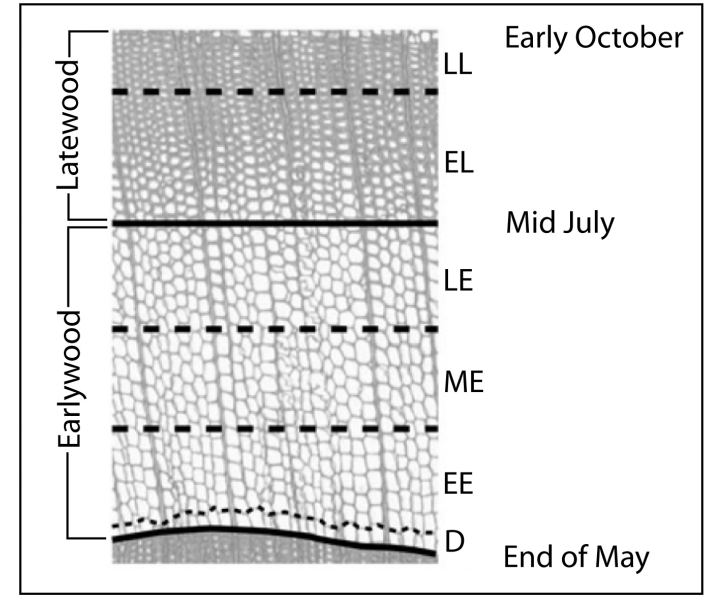

Fig. 3. Subdivisions of a tree-ring: At the study site, earlywood formation lasts from end of May to mid July, latewood formation from mid July to early October. For the assessment of intra-annual rockfall activity, tree rings are further subdivided into early (EE), middle (ME) and late (LE) earlywood as well as early (EL) and late (LL) latewood (adapted from Stoffel et al., 2005b).

TRD were taken into account if they were present (i) in an extremely compact arrangement and (ii) forming continuous rows (Stoffel et al., 2005a). In this study, we did not focus on the appearance of compression wood, as it appears delayed and therefore is not suitable to date events with intra-annual precision (Timell, 1986). Additionally, in case of several wounds within a single year, it would have been impossible to assign the reaction wood to specific injuries.

Following Stoffel et al. (2005b), the intra-annual position of injuries and the adjacent callus tissue and TRD was determined as illustrated in Fig. 3 and impacts dated to the dormant season (D), early earlywood (EE), middle earlywood (ME), late earlywood (LE), early latewood (EL) and late latewood (LL). Based on data from neighboring sites (Müller, 1980; Stoffel et al., 2005b), we know that the vegetation period of $L$. decidua, $P$. abies and $P$. cembra locally starts at the end of May with the formation of thin-walled earlywood tracheids. The transition from LE to EL occurs in mid July and the formation of thick-walled latewood tracheids ends in early October. The period between October and May is called the "dormant season" (D) and there is no cytogenesis during this time of the year.

While trees will react almost immediately to injuring events during the vegetation period (Stoffel, 2008), reactions to a rockfall impact caused during the dormant season will only be apparent at the very beginning of the "new" tree-ring.

\subsection{Orientation of rockfall impacts}

The position of the scar was assessed in the field with respect to the downslope direction. The idea behind this assessment 
Table 1. Number of trees, cross-sections and injuries analyzed.

\begin{tabular}{lll}
\hline Trees sampled & 32 \\
\hline & L. decidua & 23 \\
& P. abies & 8 \\
P. cembra & 1 \\
\hline Number of cross-sections & & 123 \\
\hline Number of injuries & & 154 \\
\hline & L. decidua & 117 \\
& P. abies & 33 \\
& P. cembra & 4 \\
\hline
\end{tabular}

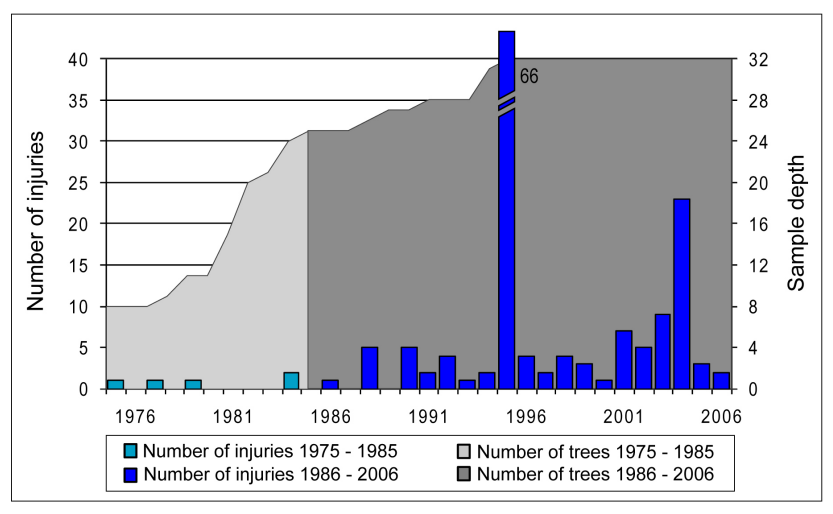

Fig. 4. Rockfall activity at Schilt as reconstructed with tree-ring analysis for the period 1975-2006. Due to the comparably young age of trees, analysis mainly focused on the period 1985-2006, when $\geq 75 \%$ of all trees were present (see sample depth).

was to approximate the source of rockfall material. Measurements were realized at the centre of each injury and the position of injuries noted in degrees $\left({ }^{\circ}\right)$. A frontal hit was attributed an impact angle of $0^{\circ}$, whereas $90^{\circ}$ and $270^{\circ}$ represent impacts located perpendicular to the general slope. Impact angles $>90^{\circ}$ and $<270^{\circ}$ stand for damage identified on the downslope part of the tree and would result from bouncing rocks and boulders leaving their marks over large parts of the tree's circumference. Results were grouped in classes of $30^{\circ}$.

\section{Results}

\subsection{General aspects}

Within this study, 32 trees were felled $(23$ L. decidua, 8 P. abies, 1 P. cembra) on the study site and 123 cross-sections prepared (Table 1), yielding a total of 154 injuries. Most frequently, one injury was identified per cross-sections, but multiple injuries were observed as well (26 cross-sections
Table 2. Tree age, tree diameter and number of injuries. Always indicating the average, the minimum value (min.), the maximum value (max.) and the standard deviation (stdev).

\begin{tabular}{lllll}
\hline & average & min. & max. & stdev \\
\hline Tree age (in years) & 25.8 & 12 & 44 & 7.5 \\
Diameter (in cm) & 9.1 & 5.4 & 15 & 2.4 \\
Injuries per tree & 4.8 & 1 & 16 & 3.2 \\
\hline
\end{tabular}

Table 3. Number of cross-sections and GD in absolute values and percentages.

\begin{tabular}{llll}
\hline & & Number & $\%$ \\
\hline Total number of cross-sections & 154 & 100 & \\
& TRD & 147 & 95.5 \\
& Callus growth & 60 & 39 \\
\hline
\end{tabular}

had 2 injuries, four cross-sections 3 injuries and one crosssection 4 injuries).

As can be seen from Table 2, age of the selected trees averaged $25.8 \mathrm{yrs}$ (STDEV: $8.0 \mathrm{yrs}$ ), with the oldest one having 44 and the youngest 12 annual rings. Seven of the selected trees were present prior to 1975 whereas the other 25 individuals germinated between 1975 and 1995. The average diameter of all sampled trees is $9.1 \mathrm{~cm}$ (STDEV: $2.4 \mathrm{~cm}$ ), representing a mean yearly diameter increase of $3.9 \mathrm{~mm}$.

The nature of growth disturbances (GD) observed on the cross-sections following rockfall impacts is illustrated in Table 3. In total, 207 GD were identified on the cross-sections as a reaction to the 154 injuring impacts. TRD represented the most common reaction to impacts and were observed in 147 cases $(95.5 \%)$. Interestingly, callus tissue was less frequently identified in the tree segments neighboring the injury and was only present on 60 cross-sections (39\%).

\subsection{Rockfall activity}

A total number of 154 injuries were dated for the period 1975-2006, resulting in an overall mean activity of 4.8 hits $\mathrm{yr}^{-1}$. Despite their predominantly young age and their rather small diameter, each tree shows a total number of 4.8 injuries in average.

The annual number of injuries as well as the sample depth (i.e. the number of trees present in a given year) is indicated in Fig. 4. It appears from the illustration that only five injuries occurred prior to 1985 , when fewer than $75 \%$ of the sampled trees were present. This is why the seasonal timing or changes in rockfall activity will only be further analyzed for the period 1985-2006, when the number of trees is sufficient to obtain a record enough complete ( $\geq 25$ trees). As a

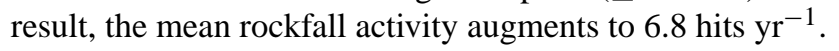




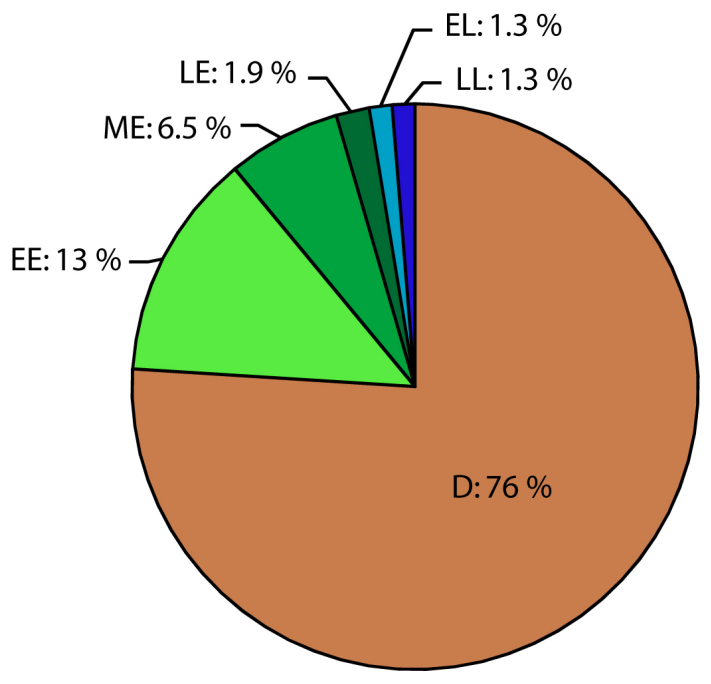

Fig. 5. Seasonal distribution of rockfall.

Figure 4 also indicates that there is a strong variation of rockfall activity between single years. Based on our data, rockfall activity was by far most important in 1995, when a total number of 66 wounds (43\%) were recorded on the cross-sections, meaning that three out of four trees would have been injured. The second largest event was reconstructed for 2004, when a total of 23 injuries was observed on the cross-sections. In contrast, we also observe years with no injuries at all $(1985,1987$ and 1989) and years with only one injury (1993 and 2000).

\subsection{Seasonal timing of rockfall}

The analysis of the intra-seasonal position of the 154 wounds and their neighboring callus tissue and TRD was used to determine the seasonal timing of rockfall activity at Schilt. Figure 5 clearly shows a concentration of injuries that would have occurred during the dormant season of trees (76\%) which locally lasts from early October to the end of May. Among the wounds located within the tree rings, it appears that rockfall is much more frequent during the period of earlywood formation (21.4\%), i.e. from end of May to mid July - than during the period of latewood formation (only $2.6 \%$ ) i.e. between mid July and early October. Examples of injuries attributed to the dormant season as well as the periods of early- and latewood formation are provided in Fig. 6 .

When going into further intra-seasonal detail for the earlywood events, it can be seen that the most significant activity (13\%) occurred in EE, followed by $6.5 \%$ of the events dated to ME and only $1.9 \%$ to LE. The numbers further decrease when analyzing the latewood events, where both EL and LL register only $1.3 \%$ of all rockfall events.

In a subsequent step, the intra-annual behavior of rockfall was assessed for all years with $\geq 5$ injuries. Table 4 provides an overview on the years that have been kept for further anal-

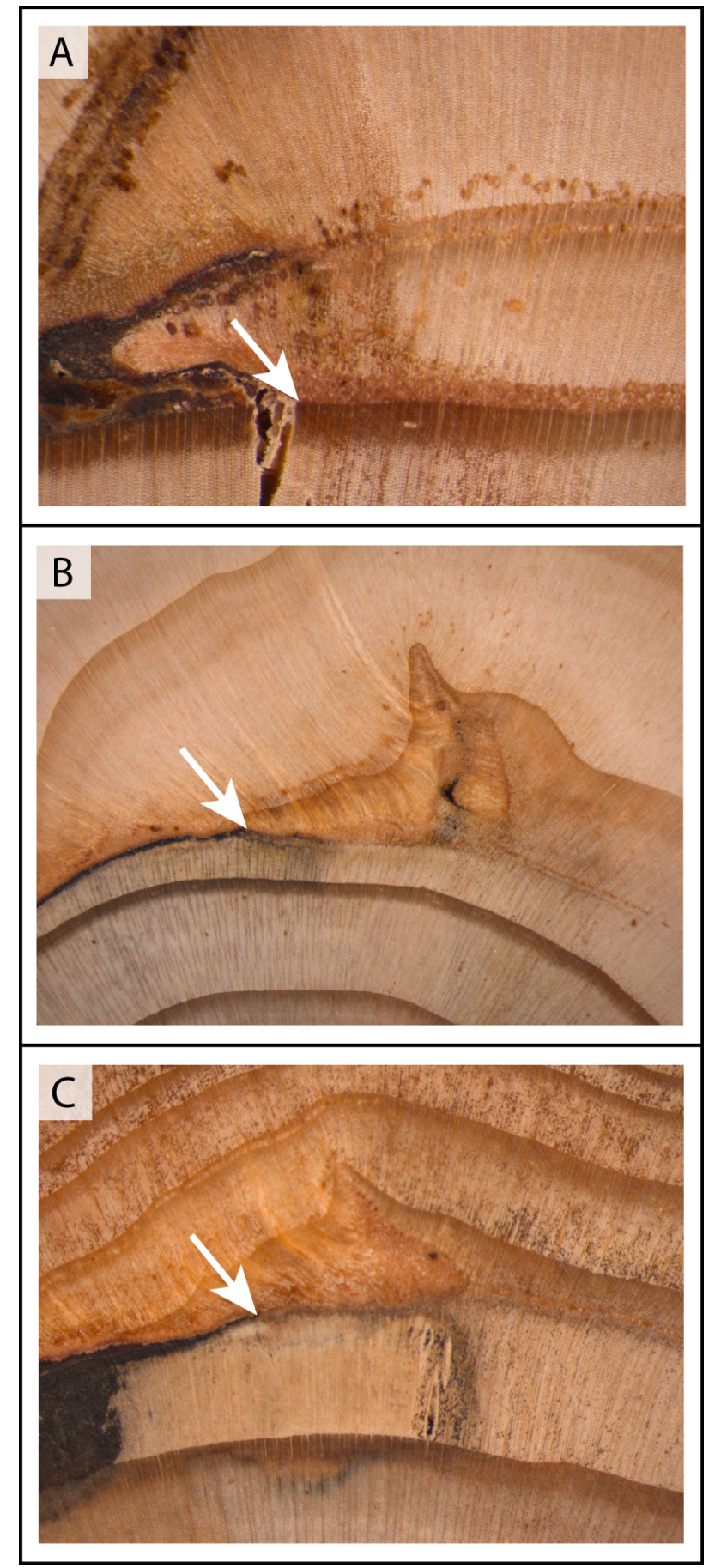

Fig. 6. Examples of rockfall injuries located at different positions within the tree ring:. Injury attributed to (A) the dormant season, (B) mid earlywood and (C) early latewood.

ysis. When analyzing the seasonal behavior of rockfall in 1995, it appears that activity was not only exceptionally high, but also different with respect to the seasonal timing of injuring events. As can be seen from Table 4, a comparably high number of impacts apparently occurred outside the dormant 
Table 4. Intra-seasonal distribution of rockfall activity at Schilt, Saas Balen. The overall distribution of rockfall $(\Sigma)$ is given in italics and rockfall activity illustrated for those years with $>5$ injuries. The abnormal seasonal distribution of rockfall activity in 1995 is highlighted with *.

\begin{tabular}{lllllllllllll}
\hline & $\mathbf{D}$ & $\boldsymbol{\%}$ & $\mathbf{E E}$ & $\boldsymbol{\%}$ & $\mathbf{M E}$ & $\boldsymbol{\%}$ & $\mathbf{L E}$ & $\boldsymbol{\%}$ & $\mathbf{E L}$ & $\boldsymbol{\%}$ & $\mathbf{L L}$ & $\boldsymbol{\%}$ \\
\hline$\sum_{\sum}$ without 1995/2004 & $\mathbf{5 2}$ & $\mathbf{5 0}$ & 20 & 13 & 10 & 6.5 & 3 & 1.9 & 2 & 1.3 & 2 & 1.3 \\
$\mathbf{2 0 0 4}$ & $\mathbf{2 0}$ & $\mathbf{8 7}$ & $\mathbf{1}$ & $\mathbf{6 . 2}$ & $\mathbf{3}$ & $\mathbf{4 . 6}$ & $\mathbf{3}$ & $\mathbf{4 . 6}$ & $\mathbf{2}$ & $\mathbf{3 . 1}$ & $\mathbf{1}$ & $\mathbf{1 . 5}$ \\
2003 & 6 & 86 & 1 & 14 & 0 & 0 & 0 & 0 & 0 & 0 & 0 & 0 \\
2002 & 5 & 100 & 0 & 0 & 0 & 0 & 0 & 0 & 0 & 0 & 0 & 0 \\
2001 & 5 & 83 & 0 & 0 & 0 & 0 & 0 & 0 & 0 & 0 & 1 & 17 \\
$\mathbf{1 9 9 5}$ & $\mathbf{4 5}$ & $\mathbf{6 8}$ & $\mathbf{1 5}$ & $\mathbf{2 3}^{*}$ & $\mathbf{6}$ & $\mathbf{9 . 1}$ & $\mathbf{0}$ & $\mathbf{0}$ & $\mathbf{0}$ & $\mathbf{0}$ & $\mathbf{0}$ & $\mathbf{0}$ \\
1990 & 4 & 80 & 0 & 0 & 0 & 0 & 0 & 0 & 1 & 20 & 0 & 0 \\
\hline
\end{tabular}

season in the early stages of the new vegetation period. Compared to the rockfall activity registered in the other years and when excluding the two major event years of 1995 and 2004, there is almost four times more activity observed in EE (23 vs. $6.2 \%$ ) and two times more activity in $\mathrm{ME}$ (9.1 vs. $4.6 \%$ ). Although rockfall was also important in 2004, the seasonal distribution of activity appears to be rather normal with just a slight concentration of events during D (87\%) and only three events within the vegetation period (13\%).

\subsection{Orientation of rockfall impacts}

The positioning of rockfall impacts with respect to the fall line (exact downslope direction) was noted in degrees $\left(^{\circ}\right.$ ) and results summarized in classes of $30^{\circ}$ each. As can be seen from Fig. 7A, the average position of injuries with respect to the fall line was $13.3^{\circ}$ and most wounds were attributed to the classes $16-45^{\circ}(24 \%), 46-75^{\circ}(14.9 \%)$ and $345-15^{\circ}(8.2 \%)$. As expected, only eight injuries $(5 \%)$ were observed on the downslope part of the stem $\left(90-270^{\circ}\right)$, probably resulting from deviated rocks and boulders. As it can be seen in illustration 7B, directional results are consistent with the geomorphic situation in the field, where the rockfall generating cliffs are located in the direction the average position of the injuries is pointing at.

\section{Discussion}

In the study we report here, 123 cross-sections from 32 trees (Larix decidua Mill., Picea abies (L.) Karst., Pinus cembra L.) were used to reconstruct yearly rockfall activity, the seasonal behavior of rockfall as well as to determine the main direction and the source areas of rockfall for the last 32 years. In total, 154 injuries were identified that have induced a total of 207 growth disturbances.

Within this study, we exclusively worked with crosssections from trees with a DBH $<15 \mathrm{~cm}$. In contrast to the analysis of increment cores where TRD can occur in later segments of the tree ring with increasing axial or tangential distance from the injury (see Bollschweiler et al., 2008), the analysis of rockfall scars on cross-sections and the identification of reactions in the tissues bordering the wound allowed an intra-annual dating with very high accuracy. The felling of comparably small trees resulted in a rather young age of samples (25.8 yrs).

Our results suggest that the formation of TRD is the most common and widespread reaction of $L$. decidua and P. abies to rockfall and was present on $95.5 \%$ of the samples. TRD can therefore be used as an excellent marker of past rockfall events, even more as no trees were showing TRD without the presence of a nearby injury. Callus tissue could, in contrast, only be assessed on $39 \%$ of the samples and was generally much less widespread within the tree ring than TRD. As our data are exclusively based on young trees and on a comparably small number of cross-sections, further research is needed to study the formation of these features following rockfall impacts.

As for the rockfall activity in individual years, the reconstruction revealed strong inter-annual differences, with major activity observed in 1995 and 2004 and other years with no events at all observed in the tree-ring records. These results correlate with findings of Stoffel et al. (2005b) or Perret et al. (2006), who both describe distinct inter-annual fluctuations of rockfall activity as well on their sites located in the Valais Alps and Bernese Oberland, respectively.

The clustering of missing injuries for several years in the early 1980s can be explained by the small number of sampled trees alive for that time, the smaller diameter and the younger age of the individuals (more flexible and therefore probably less vulnerable). It is therefore worthwhile to note that the reconstructed number of events does not represent a complete frequency reconstruction, as relevant factors (e.g. regular arrangement of sampled trees or varying tree diameters) have not been taken into consideration. The probability of an impact is therefore not evenly distributed, neither in space, nor in time. In a similar way, no clear trend can be deduced from the rockfall series we have obtained. 


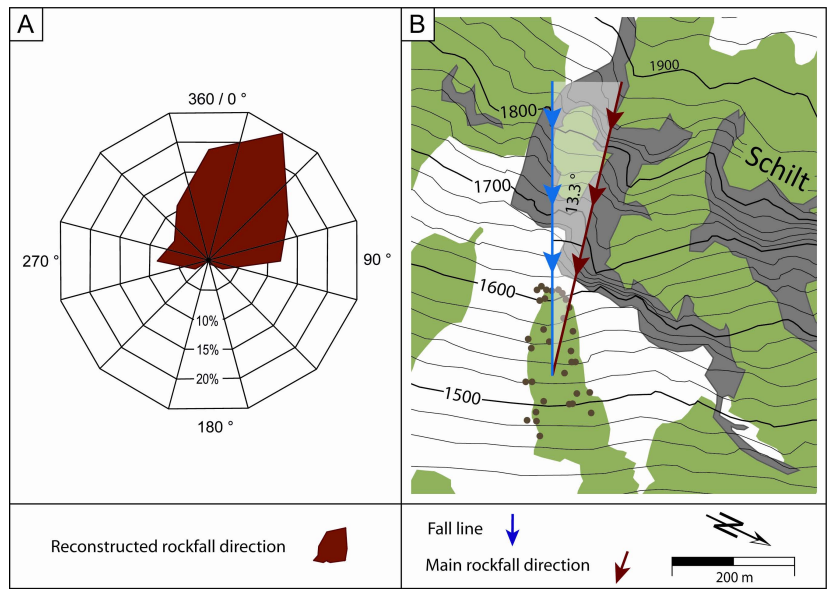

Fig. 7. (A). Radial distribution of rockfall impacts as observed on the selected trees. (B). The average rockfall direction (red) diverges from the fall line and points toward the main source area.

The intra-annual dating of injuries indicates that rockfall at Schilt predominantly occurred during the dormant season which locally lasts from early October to the end of May $(76 \%)$. Our results are in very close agreement with the findings of Perret et al. (2006) in the Diemtigtal (Swiss Prealps), reporting $74 \%$ of rockfall activity during the dormant season. In contrast, Stoffel at al. (2005b) dated a higher percentage of injuries to the dormant season (88\%) in the Matter Valley (Swiss Alps). It is most probable that the difference in the intra-annual activity of rockfall is due to the fact that there is contemporary permafrost present in the departure zone at the site studied by Stoffel et al. (2005b), but not in the cliffs of our site or in that investigated by Perret et al. (2006). Despite the concentration of rockfall activity to the dormant season, the comparably low values identified for the period of earlywood formation should not be underestimated, as more than $20 \%$ of the annual rockfall activity apparently takes places in less than two months (i.e. between the end of May and mid July). It is feasible that this concentration of rockfall activity would be the result of the annual thaw of winter ice and the circulation of melt water in preexisting fissures (Matsuoka, 2006; Hall, 2007).

Another similarity between the reconstructed data from our study site and those presented by Stoffel et al. (2005b) on rockfall activity on a slope in the neighboring Matter Valley (see Fig. 1A) is that rockfall activity was exceptionally high at both sites in 1995 .

The massive concentration of rockfall activity in 1995 allows a more detailed seasonal analysis of rockfall activity within the year, indicating that there was three times more activity occurring during $\mathrm{EE}$ and $\mathrm{ME}$ as compared to the mean distribution. Apart from occasional freeze-thaw cycles or the melting of ice, it is possible that heavy precipitation events could have led to this concentrated and massive re-

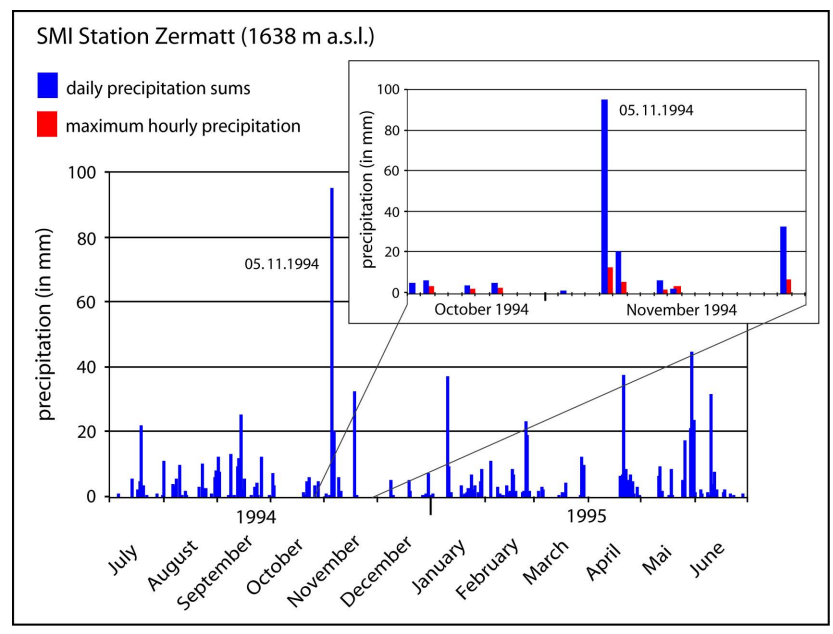

Fig. 8. Meteorological data from the SMI station Zermatt confirm exceptionally high daily precipitation (in blue) recorded on 5th November 1994 with $94.4 \mathrm{~mm} / 24 \mathrm{~h}$. This represents the most intense rainfall for at least 25 years. The hourly maximum attained during this event was $11.3 \mathrm{~mm}$ (in red), indicating a persistent intense rainfall rather than an extreme and short thunderstorm.

lease of rocks and boulders. Meteorological data from a station in Zermatt (located $20 \mathrm{~km}$ to the south-west of the study site; SMI 2007) indicate indeed exceptionally heavy precipitation events for the dormant season of 1994-1995, with the heaviest daily precipitation sum for at least the last 25 years recorded on 5 November 1994 (Fig. 8). As the local meteorological station of Saas Balen is only operational since December 1994, we do not have any indications on the intensity of this precipitation event at the study site. Similarly and based on the air temperatures measured at Zermatt, it is not quite clear whether the precipitation at our study site was in the form of rain or snow. In contrast, the local meteorological station recorded the second most important precipitation event between 1994 and today on 21 April 1995. As the two rockfall sites in the two neighboring valleys (Stoffel et al., 2005b, our study site) presumably reacted to the same triggering events, we suppose that the concentration of several precipitation events affecting large parts of the Valais Alps would be at the origin of the much higher frequency of rockfall in the first half of 1995.

We also have to admit that the response of the cliffs in generating rockfall following the precipitation may appear to be delayed. There are two possible explanations for this delay: Air temperatures may have dropped suddenly after the heavy rainfalls in November 1994 and/or April 1995, leading to abnormally large quantities of water frozen in the cracks. On the other hand, it is feasible that snowfall occurred during both events, leading to large quantities of water flowing through the cracks during snow melt.

Data obtained on the position of scars on the stem surface and the resulting back tracing of "rockfall trajectories" are 
in very good agreement with the geomorphic situation in the field, as the main direction of rockfall pointed towards the main rockfall source area. We are well aware that falling rocks and boulders may be deviated during ground contact and by impacting other trees further up on the slope, nevertheless results indicate that some directional information was preserved.

\section{Conclusions}

Tree-ring analysis allowed inter-annual dating of 154 past rockfall injuries between 1975 and 2006 as well as the assessment of intra-seasonal behavior of rockfall at the study site. We conclude that the tree-ring analysis delivers exceptionally good data on the inter- as well as intra-annual behavior of rockfall and that it furnishes valuable information on the activity of rockfall source areas. At the same time and as rockfall activity peaks during the dormant season of trees, it is not possible to date these events with higher temporal resolution.

Acknowledgements. The authors acknowledge the valuable comments from the reviewers D. R. Butler and J. Moya. They are also grateful to M. Bollschweiler for her assistance in the field and lab and for the many insightful comments on earlier versions of this paper. Furthermore we would like to thank L. Correa for his assistance in the field and O. Hitz for his valuable comments on wood anatomy. Finally, we kindly thank the local administration and the forester for allowing us to work in their forest.

Edited by: M. Bollschweiler

Reviewed by: D. Butler and J. Moya

\section{References}

Azzoni, A., Barbera, G. L., and Zaninetti, A.: Analysis and prediction of rockfalls using a mathematical model, Int. J. Rock. Mech. Min., 32, 709-24, 1995.

Bearth, P.: Geologischer Atlas der Schweiz 1:25000, Niklaus, (Atlasblatt 71), Schweizerische Geologische Kommission, 1980.

Bearth, P.: Geologischer Atlas der Schweiz 1:25000, Simplon, (Atlasblatt 61), Schweizerische Geologische Kommission, 1973.

Berger, F., Quetel, C., and Dorren, L. K. A.: Forest: A natural protection mean against rockfall, but with which efficiency? The objectives and methodology of the ROCKFOR project, Interpavement 2002, 2, 815-826, 2002.

Bollschweiler, M., Stoffel, M., Schneuwly, D. M., and Bourqui, K.: Traumatic resin ducts in Larix decidua stems impacted by debris flows, Tree Physiol., 28, 255-263, 2008.

Bozzolo, D., Pamini, R., and Hutter, K.: Rockfall analysis - a mathematical model and its test with field data, Proceedings of the 5th International Symposium on Landslides in Lausanne, Rotterdam, Balkema, 555-60, 1986.

Braam, R. R., Weiss, E. E. J., and Burrough, P. A.: Spatial and temporal analysis of mass movement using dendrochronology, Catena, 14, 573-584, 1987.
Bräker, O. U.: Measuring and data processing in tree-ring research - a methodological introduction, Dendrochronologia, 20, 203216, 2002.

Butler, D. R.: Rockfall hazard inventory, Ram River, Mackenzie Mountains, The Canadian Geographer, 27, 2, 175-178, 1983.

Coe, J. A. and Harp, E. L.: Influence of tectonic folding on rockfall susceptibility, American Fork Canyon, Utah, USA, Nat. Hazards Earth Syst. Sci., 7, 1-14, 2007, http://www.nat-hazards-earth-syst-sci.net/7/1/2007/.

Davies, M. C. R., Hamza, O., and Harris, C.: The effect of rise in mean annual temperature on the stability of rock slopes containing ice-filled discontinuities, Permafrost Periglac., 12, 1, 137144, 2001.

Dorren, L. K. A., Berger, F., and Putters, U. S.: Real size experiments and 3D simulation of rockfall on forested and non-forested slopes, Nat. Hazards Earth Syst. Sci., 6, 145-153, 2006, http://www.nat-hazards-earth-syst-sci.net/6/145/2006/.

Douglas, G. R.: Magnitude frequency study of rockfall in Co. Antrim, N. Ireland, Earth Surf. Proc. Land., 5, 2, 123-129, 1980.

Erismann, T. H.: Flowing, rolling, bouncing, sliding, synopsis of basic mechanisms, Acta Mech., 64, 101-110, 1986.

Evans, S. G. and Hungr, O.: The assessment of rockfall hazard at the base of talus slopes, Can. Geotech. J., 30, 620-36, 1993.

Gardner, J.: Rockfall frequency and distribution in the Highwood Pass area, Canadian Rocky Mountains, Z. Geomorphol., 27, 311-24, 1983.

Gardner, J. S.: Frequency, magnitude, and spatial distribution of mountain rockfalls and rockslides in the Highwood Pass Area, Alberta, Canada, in: Thresholds in Geomorphology, edited by: Coates, R., Vitek, J. D., Allen and Unwin, New York, 267-295, 1980.

Gruber, S., Hoelzle, M., and Haeberli, W.: Permafrost thaw and destabilization of Alpine rock walls in the hot summer of 2003, Geophys. Res. Lett., 31, L13504, doi:10.1029/2004GL020051, 2004.

Guzzetti, F., Crosta, G., Detti, R., and Agliardi, F.: STONE: a computer program for the three-dimensional simulation of rock-falls, Computers and Geosciences, 28, 9, 1079-1093, 2002.

Hall, K.: Evidence for freeze-thaw events and their implications for rock weathering in northern Canada. II. The temperature at which water freezes in rock, Earth Surf. Proc. Land., 32, 2, 249259, 2007.

Harp, E. L. and Wilson, R. C.: Shaking intensity thresholds for rock falls and slides: Evidence from 1987 Whittier Narrows and superstition hills earthquake strong-motion records, B. Seismol. Soc. Am., 85, 6, 1739-1757, 1995.

Hungr, O. and Evans, S. G.: Engineering evaluation of fragmental rockfall hazards, Proceedings of the 5th International Symposium on Landslides in Lausanne, Rotterdam, Balkema, 685-90, 1988.

Kirkby, M. J. and Statham, I.: Surface stone movement and scree formation, J. Geol., 83, 349-62, 1975.

Lafortune, M., Filion, L., and Hétu, B.: Dynamique d'un front forestier sur un talus d'éboulis actif en climat tempéré froid (Gaspésie, Québec), Géogr. Phys. Quat, 51, 1, 1-15, 1997.

Luckman, B. H.: Rockfalls and rockfall inventory data; some observations from the Surprise Valley, Jasper National Park, Canada, Earth Surf. Proc. Land., 1, 287-98, 1976.

Luckman, B. H. and Fiske, C. J.: Estimating long-term rockfall 
accretion rates by lichenometry, Slaymaker, O. (Ed.), Steepland Geomorphology, Wiley, Chichester, 233- 255, 1995.

Marzorati, S., Luzi, L., and De Amicis, M.: Rock falls induced by earthquakes: a statistical approach, Soil Dyn. Earthq. Eng., 22, 7, 565-577, 13, 2002.

Matsuoka, N.: Frost wedging and rockfalls on high mountain rock slopes: 11 years of observations in the Swiss Alps, Geophys. Res. Abstr., 8, 05344, European Geosciences Union, 2006.

Matsuoka, N. and Sakai, H.: Rockfall activity from an alpine cliff during thawing periods, Geomorphology, 28, 3, 309-328, 1999.

McCarroll, D., Shakesby, R. A., and Matthews, J. S.: Spatial and temporal patterns of Late Holocene rockfall activity on a Norwegian talus slope: lichenometry and simulation-modelling approach, Arct. Alp. Res., 30, 51-60, 1998.

Müller, H.-N.: Jahrringwachstum und Klimafaktoren: Beziehungen zwischen Jahrringwachstum von Nadelbaumarten und Klimafaktoren an verschiedenen Standorten im Gebiet des Simplonpasses (Wallis, Schweiz), Forstl. Bundes-Versuchsanst., Wien 25, Agrarverlag, Wien, p. 81, 1980.

Okura, Y., Kitahara, H., Sammori, T., and Kawanami, A.: The effects of rockfall volume on runout distance, Eng. Geol., 58, 2, 109-124(16), 2000.

Perret, S., Stoffel, M., and Kienholz, H.: Spatial and temporal rockfall activity in a forest stand in the Swiss Prealps - a dendrogeomorphological case study, Geomorphology, 74, 219-231, 2006.

Ritchie, A. M.: Evaluation of rockfall and its control, Washington, DC: Highway Research Board, National Research Council, Highway Research Record, 17, 13-28, 1963.

Ruppen, P. J., Imseng, G., and Imseng, W.: Saaser Chronik 12001979, Rotten-Verlag, Brig, p. 54, 1979.

Sass, O.: Temporal Variability of Rockfall in the Bavarian Alps, Germany, Arct. Antarct. Alp. Res., 37, 4, 564-573, 2005.

Schweingruber, F. H.: Tree Rings and Environment, Dendroecology, Paul Haupt, Bern, p. 82, 1996.

Schweingruber, F. H.: Holzanatomie, Paul Haupt, Bern, 334-345, 2001.

Shroder, J. F.: Dendrogeomorphology: Review and new techniques of tree-ring dating, Prog. Phys. Geog., 4, 161-188, 1980.

SMI (Swiss Meteorological Institute): Annals of the Swiss Meteorological Institute, daily precipitation sums 1982-2007, Zurich, http://www.sma.ch, 2007.
Solomina, O. N.: Dendrogeomorphology: Research Requirements, Dendrochronologia, 20, 1, 231-243, 2002.

Statham, I. and Francis, S. C.: Influence of scree accumulation and weathering on the development of steep mountain slopes, Abrahams, A. D. (Ed.), Hillslope processes, Winchester, Allen and Unwin Inc., 245-67, 1986.

Stoffel, M., Schneuwly, D., Bollschweiler, M., Lièvre, I., Delaloye, R., Myint, M., and Monbaron, M.: Analyzing rockfall activity (1600-2002) in a protection forest - a case study using dendrogeomorphology, Geomorphology, 68, (3-4), 224-241, 2005a.

Stoffel, M., Lièvre, I., Monbaron, M., and Perret, S.: Seasonal timing of rockfall activity on a forested slope at Täschgufer (Valais, Swiss Alps) - a dendrochronological approach, Z. Geomorphologie, 49, 1, 89-106, 2005b.

Stoffel, M., Bollschweiler, M., and Hassler, G.-R.: Differentiating past events on a cone influenced by debris-flow and snow avalanche activity - a dendrogeomorphological approach, Earth Surf. Proc. Land., 31, 1424-1437, 2006 a.

Stoffel, M., Wehrli, A., Kühne, R., Dorren, L. K. A., Perret, S., and Kienholz, H.: Assessing the protective effect of mountain forests against rockfall using a 3D simulation model, Forest. Ecol. Manag., 225, 113-122, 2006 b.

Stoffel, M., Conus, D., Grichting, M. A., Lièvre, I., and Mâitre, G.: Unraveling the patterns of late Holocene debris-flow activity on a cone in the Swiss Alps: Chronology, environment and implications for the future, Global Planetary Change, 60, 222-234, 2008.

Stoffel, M.: Dating past geomorphic processes with tangential rows of traumatic resin ducts, Dendrochronologia, in press, 2008.

Stokes, M. A. and Smiley, T. L.: An Introduction to Tree-Ring Dating, Chicago, University of Chicago Press, 73 pp., 1968.

Timell, T. E.: Compression wood in gymnosperms, SpringerVerlag, Berlin, 2150 pp., 1986.

Wiles, G. C., Calkin, P. E., and Jacoby, G. C.: Tree-ring analysis and Quaternary geology: Principles and recent applications, Geomorphology, 16, 259-272, 1996. 